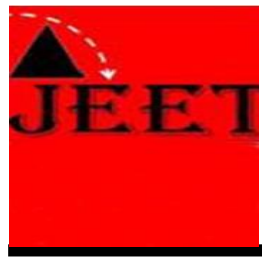

\title{
Developing English Materials for Nursing Students through Students' Need Analysis
}

\author{
Kristian Burhan \\ Universitas Nahdlatul Ulama Sumatera Barat \\ misterkrist88@gmail.com \\ Hendra Putra \\ Universita Fort de Kock Bukittinggi \\ hendraputra@fdk.ac.id \\ Corresponding email: misterkrist88@gmail.com
}

\begin{abstract}
The study aims to find out the nursing students of AKPER YPTK Solok need in developing English materials. This research is classified as mixed method research design; qualitative research and survey research. In this research, there are two instruments; questionnaire and interview guidelines. The questionnaire aims to gain and collect information from students related to English teaching and learning. Interview guideline is used to gather information from English lecturer at AKPER YPTK Solok. The results of this research show that; (1) there are some skills and English components that are needed by the nursing students of AKPER YPTK Solok, they are; speaking skill, reading skill, vocabulary mastery, and grammar mastery. (2) This research also found that nursing students of AKPER YPTK Solok want English materials, including grammar and vocabulary related to nursing field to be more focused in teaching and learning process. Based on the results, it can be concluded that in developing English materials for nursing students, the lecturers and decision maker should know what the students and work field need through students; need analysis.
\end{abstract}

Keywords: English for Specific Purpose (ESP), Need Analysis.

\section{Introduction}

English is a compulsory subject that must be studied by all nursing students. English for nursing students is focused on developing skills in the understanding of materials that is tailored to the context of the profession; Nursing. English for nursing needs certain understanding related to application in work field, it is called English for Specific Purposes (ESP). English for Specific Purpose (ESP) is referred to as English that is devoted to a specific purpose, such as hospitality, health, law, etc. Lenzo (2005) says "ESP students are typically adults who already have some understanding of English and learn the language to communicate a set of professional skills and perform certain function-related jobs." Furthermore, English for Specific Purpose (ESP) is different from general English. General English is aimed at improving students' abilities in using English. General English teaches five standards of learning about (a) 
subject matter, (b) vocabulary and structure, (c) exercises, (d) illustrations, and (e) make physical up (Chegeni: 2006). It means that the students are given standard and basic English as a second language or foreign language. English for Specific Purposes (ESP) is designed based on special needs related to the work or academic of students, and offer description of the use of language in the discipline or occupation they serve (Basturkmen: 2010). Therefore, ESP is designed and developed based on the concept of need analysis.

Need analysis assesses the need students' communicative and technique achievement of specific learning goals. Need analysis is done to identify what will be done by the students with a foreign language in specific situations and how the student master the target language during the learning process (Dudley, E. and St Johns: 1998). Moreover, need Analysis in ESP that aims at make English taught really needed in accordance with the field that is being pursued by students, especially for nursing students that contains three aspects; lack, wants and necessity. Certainly, in the implementation, these three aspects and getting information is needed by students.

According to Kim (2013) there are eight components in the concept of need analysis. It has now been grouped into five broad areas, consisting of: (a) targets situation analysis and objective needs (e.g. student tasks and activities will/in Using English; (b) linguistic analysis, discourse analysis, genre analysis, namely knowledge of how languages and skills are used in targets situation; (c) subjective needs, i.e. student wants, meaning, subjective-factor needs which affects the way they learn (e.g. previous learning experiences, reasons to take the course, hope); (d) present situation analysis for the purpose of identifying skills and use of language today; (e) means analysis, i.e. information about the environment in which learning will be carried out. So it can be concluded that in development of English materials for specific purposes using these five components.

There are some previous researches that related to explanation above: first, the research conducted by Uli Agustin Gulto (2016) entitled "The Developing English Learning Materials for Nursing Students of Borneo University Tarakan", the results of this study say that English learning materials for students of nursing has several components; goals, input, procedures, setting, teacher roles and learners roles. Second, the research has been conducted by Wahyudi (2016) entitle, "Developing English Learning Materials Based on Content-Based Approach for Nursing Students of 
STIKES Payung Negeri Pekanbaru", the results of this study say that English language material is needed by students related to hospital, nursing care, medical treatment, diseases, and medicines.

Related to the previous studies above, this research conducted the small observation, it is found that learning English materials for nursing students have not been in accordance with the needs profession of a nurse. At this time, English courses are given more much to do with general English which is not in accordance with ESP learning objectives for nursing students. Then, English materials that are used by the lecturer have not been appropriate and the lecturer has not developed the English materials appropriately based on what the students need in teaching learning process. Therefore, teaching and learning materials that are in accordance with nursing competence needs to be developed. Development of learning materials is expected to be used as a guideline for developing or compiling materials such as modules or teaching books for nursing students. Based on the explanation above, it is conducted the research entitled "English for Specific Purpose: Developing English Materials for Nursing Students through Students' Need Analysis."

\section{Research Methodology,}

This research was qualitative research. Qualitative research related to comprehensive collection, analysis and interpretation, narrative and visual data in order to gain insight into a particular phenomenon of interest (Gay: 2006). This research was also survey research. This survey research provides an overview of the data. It means that researcher conducts a survey of the sample or in the population of students to describe the level of attitude, behavior and characteristics of the population itself. In this survey research, it gathered the information in an organized way about the characteristics of a population using methodological concepts and good procedures (Cresswell: 2009).

The subjects in this research consisted of; (a) the first year of nursing students of AKPER YPTK Solok, the total numbers were 30 students. These subjects had taken English course in the first semester and second semester; (b) English lecturer, to find out the interests of students, availability of teaching materials, and students activities. This research used questionnaires and interviews as the instruments. Questionnaire prepared by entering indicators from need analysis. Questionnaires were distributed 
to students to get the information needed. After getting the information through the questionnaires. Interview guides that were used to interview the English lecturer.

Technique data analysis of this research were; Questionnaires were formed on the same scale. Students asked to provide a tick $(\sqrt{ })$ on statements that based on their needs. Interview data from lecturer was analyzed to support the students' response of who had filled out questionnaires about their need for English and their awareness on English. After getting the results and information that were needed, this research analyzed the data to obtain valid and relevant information. The interview data was recorded. The recording transcribed and used as supporting data to answer research questions. After getting the results and information needed, this research analyzed the data to obtain valid and relevant information and made a description of the findings obtained from data analyzing and description results. In addition, it could be seen that materials were needed by nursing students in English learning. The results of the data analysis used as consideration for developing English materials for nursing students.

\section{Findings and Discussion}

\section{Findings}

There are three components of need analysis that are analyzed in this research, they are; necessity, lack, and want.

\section{Students' Necessity}

After analyzed the data of students' necessity or interest in English, the data can be seen in the table below:

Table 1. Students' Necessity Data

\begin{tabular}{|c|c|c|c|c|c|c|c|c|}
\hline \multirow{2}{*}{$\begin{array}{c}\text { English Skills and } \\
\text { Components }\end{array}$} & \multicolumn{2}{|c|}{$\begin{array}{c}\text { Very } \\
\text { Important }\end{array}$} & \multicolumn{2}{|c|}{ Important } & \multicolumn{2}{|c|}{$\begin{array}{c}\text { Less } \\
\text { Important }\end{array}$} & \multicolumn{2}{|c|}{ Not Important } \\
\hline & $F$ & $\%$ & $F$ & $\%$ & $\mathbf{F}$ & $\%$ & $F$ & $\%$ \\
\hline $\begin{array}{l}\text { Four English Skills, } \\
\text { including; } \\
\text { Grammar and } \\
\text { Vocabulary }\end{array}$ & 19 & $63.33 \%$ & 11 & $36.67 \%$ & 0 & $0 \%$ & 0 & $0 \%$ \\
\hline Listening skill & 14 & $46.67 \%$ & 16 & $53.33 \%$ & 0 & $0 \%$ & 0 & $0 \%$ \\
\hline
\end{tabular}




\begin{tabular}{|l|c|c|c|c|c|c|c|c|}
\hline Speaking Skill & 23 & $76.67 \%$ & 7 & $23.33 \%$ & 0 & $0 \%$ & 0 & $0 \%$ \\
\hline Reading Skill & 19 & $63.33 \%$ & 11 & $36.67 \%$ & 0 & $0 \%$ & 0 & $0 \%$ \\
\hline Writing Skill & 15 & $50 \%$ & 15 & $50 \%$ & 0 & $0 \%$ & 0 & $0 \%$ \\
\hline $\begin{array}{l}\text { Vocabulary } \\
\text { Mastery }\end{array}$ & 19 & $63.33 \%$ & 11 & $36.67 \%$ & 0 & $0 \%$ & 0 & $0 \%$ \\
\hline Grammar Mastery & 20 & $66.67 \%$ & 10 & $33.33 \%$ & 0 & $0 \%$ & 0 & $0 \%$ \\
\hline
\end{tabular}

Based the table 1 above can be seen that there are $63.33 \%$ students said all English skills including vocabulary and grammar are very important to be learned in AKPER YPTK Solok. For listening skill, there are $46.67 \%$ students say that Listening skill is very important, and the students who say Listening skill is important, there are $53.33 \%$ students, and there is no one student who say that Listening skill are less important or not important. Therefore, it can be concluded that listening skill is important to be learned by the students of AKPER YPTK Solok.

For Speaking skills, there are $76.66 \%$ say that it is very important to be learned, there are $23.37 \%$ students say that speaking skill are important, and no student say Speaking skill is less important and not important. Furthermore, for Reading skills, students of AKPER YPTK Solok who say that reading skill is very important, there are $63.33 \%$, there are $36.67 \%$ students who say that reading skill is important, and no students say reading skill is less important or not important. Based on the highest percentage. Next, for writing skill, there are $50 \%$ students of AKPER YPTK Solok say that writing skill is very important, and there are $50 \%$ of students also say that wiring skill is important. For vocabulary mastery, there are $63.33 \%$ students of AKPER YPTK Solok who say that vocabulary is very important, and $36.67 \%$ students say that vocabulary mastery is important, and no student say vocabulary mastery is less important or not important. In terms of grammar mastery, there are $66.67 \%$ students said that grammar mastery is very important, and $33.33 \%$ of students say that grammar mastery is important. Therefore, both of vocabulary and grammar mastery are really needed by the students of AKPER YPTK Solok in order to they are able to understand and use English well in work field.

\section{Students' Lack}

After analyzed the data of students' lack, the data can be seen in the table below: 
Table 2. Students' Lack Data

\begin{tabular}{|l|c|c|c|c|c|c|c|c|}
\hline \multicolumn{1}{|c|}{$\begin{array}{c}\text { English Skills and } \\
\text { Components }\end{array}$} & \multicolumn{2}{c|}{ Excellent } & \multicolumn{2}{c|}{ Good } & \multicolumn{2}{c|}{ Sufficient } & \multicolumn{2}{c|}{ Poor } \\
\cline { 2 - 9 } & F & $\%$ & F & $\%$ & F & $\%$ & F & $\%$ \\
\hline $\begin{array}{l}\text { Four English } \\
\text { including; Grammar } \\
\text { and Vocabulary }\end{array}$ & 2 & $6.67 \%$ & 15 & $50 \%$ & 12 & $40 \%$ & 1 & $3.33 \%$ \\
\hline Listening skill & 4 & $13.33 \%$ & 9 & $30 \%$ & 14 & $46.67 \%$ & 3 & $10 \%$ \\
\hline Speaking Skill & 2 & $6.67 \%$ & 11 & $36.67 \%$ & 13 & $43.33 \%$ & 4 & $13.33 \%$ \\
\hline Reading Skill & 8 & $26.67 \%$ & 13 & $43.33 \%$ & 7 & $23.33 \%$ & 2 & $6.67 \%$ \\
\hline Writing Skill & 8 & $26.67 \%$ & 12 & $40 \%$ & 9 & $30 \%$ & 1 & $3.33 \%$ \\
\hline Vocabulary Mastery & 4 & $13.33 \%$ & 11 & $36.67 \%$ & 14 & $46.67 \%$ & 1 & $3.33 \%$ \\
\hline Grammar Mastery & 3 & $10 \%$ & 11 & $36.67 \%$ & 13 & $43.33 \%$ & 3 & $10 \%$ \\
\hline
\end{tabular}

Based the data on the table 2 above, it can be explained that AKPER YPTK

Solok students for mastery or initial knowledge of students of all English language skills are $50 \%$ in the Good category. The students of AKPER YPTK Solok who say that they have excellent skill in all English skills are $6.67 \%$ students, and there are $40 \%$ students say that they have the initial ability of all English skills are sufficient, and the students who say the initial skill of all skills is poor, there are $3.33 \%$ students.

In listening skills, there are $13.33 \%$ students of AKPER YPTK Solok who have excellent initial skill. For good initial listening skill, it has $30 \%$ students and there are $46.67 \%$ students have less listening initial skill. Furthermore, there are $10 \%$ students who have the initial listening skill is poor. For speaking skills, the students of AKPER YPTK Solok who have excellent initial speaking skill, there are $6.67 \%$ of students. There are $36.67 \%$ students have good initial speaking skill. Furthermore, the students who have less initial speaking skill, there are $43.33 \%$ students and $13.33 \%$ students have poor initial speaking skill. For reading skill, the students of AKPER YPTK Solok who have excellent initial skill, there are $26.67 \%$ students. There are $43.33 \%$ students have good initial reading skill. The students who have the initial reading skill in sufficient category, there are $23.33 \%$ students. Then, there are $6.67 \%$ students still have poor initial skill. Thus, for reading skills, students already have good initial skill in reading with the percentage of $43.33 \%$ and there are still some percent of students who have poor initial skill. In writing skills, there are $26.67 \%$ students of AKPER YPTK Solok students have excellent in writing skill. The students who have good in writing skills are $40 \%$ students. 
Next, the students who have sufficient in writing skill are $30 \%$ students. There are $3.33 \%$ students have poor in writing skill.

Furthermore, for vocabulary mastery, there are $13.33 \%$ students of AKPER YPTK Solok have excellent vocabulary mastery. Students are in good vocabulary mastery, there are $36.67 \%$ students. There are $46.67 \%$ students are in sufficient vocabulary sufficient. Then, there are $3.33 \%$ students who have poor vocabulary mastery. Furthermore, in grammar mastery, there are $10 \%$ students of AKPER YPTK Solok are in excellent category. The students who have good grammar mastery, there are $36.67 \%$ students. There are $43.33 \%$ students are sufficient grammar mastery. Then, there are $10 \%$ students have poor grammar.

\section{Students' Wants}

After analyzed the data of students' wants, the data can be seen in the table below:

\begin{tabular}{|c|c|c|c|c|c|c|c|c|c|}
\hline \multirow[t]{2}{*}{ No. } & \multirow[t]{2}{*}{ Statements } & \multicolumn{2}{|c|}{ Strongly Agree } & \multicolumn{2}{|c|}{ Agree } & \multicolumn{2}{|c|}{ Less Agree } & \multicolumn{2}{|c|}{ Disagree } \\
\hline & & $\mathbf{F}$ & $\%$ & $\mathbf{F}$ & $\%$ & $F$ & $\%$ & $\mathbf{F}$ & $\%$ \\
\hline 1. & $\begin{array}{l}\text { English Materials } \\
\text { related to major } \\
\text { (Nursing) }\end{array}$ & 15 & 50 & 7 & $23.33 \%$ & 5 & $16.67 \%$ & 3 & $10 \%$ \\
\hline 2. & $\begin{array}{l}\text { Addition } \\
\text { authentic } \\
\text { materials related } \\
\text { to major (Nursing) }\end{array}$ & 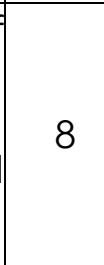 & $26.67 \%$ & 12 & $40 \%$ & 7 & $23.33 \%$ & 3 & $10 \%$ \\
\hline 3. & $\begin{array}{l}\text { Vocabulary and } \\
\text { grammar mastery } \\
\text { materials focus on } \\
\text { the development } \\
\text { of nursing field }\end{array}$ & 12 & $40 \%$ & 8 & 26.67 & 6 & $20 \%$ & 4 & $13.33 \%$ \\
\hline 4. & $\begin{array}{lr}\text { Addition } & \text { time to } \\
\text { make } & \text { teaching } \\
\text { and } & \text { learning } \\
\text { process } & \text { more } \\
\text { effective } & \end{array}$ & 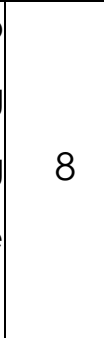 & 26.67 & 10 & $33.33 \%$ & 7 & $23.33 \%$ & 5 & $16.67 \%$ \\
\hline
\end{tabular}


Based on the table above, there are $50 \%$ students of AKPER YPTK said they strongly agree if the English lecture material is related to nursing. The students who agreed English materials related to nursing, there are $23.33 \%$ students. Furthermore, there are $16.67 \%$ students who say they less agree if English materials are only focused on nursing. Even there are $10 \%$ students who say they disagree if English materials is only focused nursing.

Furthermore, the addition of authentic materials related to nursing, there are 26.67\% students of AKPER YPTK Solok who say that they strongly agree with this. About $40 \%$ students say that they agree with the addition of authentic materials related to nursing. The students who less agree with this there are about $23.33 \%$, and $10 \%$ students say that they disagree with the addition of authentic materials related to nursing. For the development of vocabulary and grammar mastery materials focusing on the development of the field of nursing, there are $40 \%$ students of AKPER YPTK Solok strongly agree with this. In addition, there are $26.67 \%$ students said that they agreed with the development of vocabulary and grammar mastery materials focusing on the development of the field of nursing About $20 \%$ students said they less agreed with the development of vocabulary and grammar mastery materials focusing on the development of nursing. There are $13.33 \%$ students said they disagreed with the development of vocabulary and grammar mastery materials focusing on the development of nursing.

Related to the addition of time to make learning more effective, there are $26.67 \%$ students of AKPER YPTK Solok said that they strongly agree with the addition of time to make learning more effective. There are $33.33 \%$ students that they agree with the addition of lecture time to make learning more effective. Students who less agree with the addition of lecture time to make learning more effective, there are 23.33\%. There are $16.67 \%$ students who say that they disagree with the addition of lecture time to make learning more effective.

\section{Discussion}

This research used two instruments; questionnaire and interview guidelines. Questionnaire was distributed to 30 students of AKPER YPTK Solok. In this research questionnaire, there are three aspects of need analysis, namely; necessity, lacks, and wants. According to Dudley and John (1998), need analysis is done to identify 
what will be done by the students with a foreign language in specific situations and how the student master the target language during the learning process.

After analyzed the data of questionnaire, it can be seen that there are $63.33 \%$ students said all English skills including vocabulary and grammar are very important to be learned in AKPER YPTK Solok. Based on result that has been explained above, it can be seen that the initial skill of AKPER YPTK students is in good category. Then, there are $76.67 \%$ shows that the students' necessity on speaking skill.

Based on the students' lack data, there are four English skills; listening skill, speaking skill, reading skill, and writing skill. For listening skill, there are $46.67 \%$ students are in sufficient category. It means that, the students' listening skill need improvement. For speaking skill, there are $43.33 \%$ students are in sufficient category. This data said that the speaking skill of AKPER YPTK Solok students also need improvement. Next, reading skill, there are $43.33 \%$ students are in good category. It can be said that the students' reading skill has been good. The last, writing skill, there are $40 \%$ students are in good category. Thus, students' writing skill has been good. Next, for English components; vocabulary and grammar. The students' vocabulary mastery can be said sufficient with $46.67 \%$ students are in sufficient. Thus, students' vocabulary needs improvement, especially in nursing, in order to the students can improve their other skills. Next, the students' grammar mastery is sufficient, it is indicated by $43.33 \%$ students are in sufficient category. It means that, students' grammar mastery also needs improvement. Moreover, based on the students' wants, it can be seen that what the students want and what the materials that students need can be analyzed that students tend to prefer to learn skills, vocabulary, and grammar related to nursing field. The students of AKPER YPTK Solok also want authentic material and skills related to what the work field needs in the future. Thus, it can be said that the students of AKPER YPTK Solok needs for English courses related to teaching materials.

The results above related to Kim (2013) who say there are eight components in the concept of need analysis that had been grouped into five broad areas, consisting of: (a) targets situation analysis and objective needs (e.g. student tasks and activities will/in Using English; (b) linguistic analysis, discourse analysis, genre analysis, namely knowledge of how languages and skills are used in targets situation; (c) subjective needs, i.e. student wants, meaning, subjective-factor needs which affects the way they learn (e.g. previous learning experiences, reasons to take the 
course, hope); (d) present situation analysis for the purpose of identifying skills and use of language today; (e) means analysis, i.e. information about the environment in which learning will be carried out. So it can be concluded that in development of English materials for specific purposes using these five components.

Next, Related to the previous studies, the research conducted by Uli Agustin Gulto (2016) entitled "The Developing English Learning Materials for Nursing Students of Borneo University Tarakan", the results of this study say that English learning materials for students of nursing has several components; goals, input, procedures, setting, teacher roles and learners roles. The result of her research more focuses on procedures in teaching and learning process, comparing to the research that researcher conducted focusing on students' need on materials. Second, the research has been conducted by Wahyudi (2016) entitle, "Developing English Learning Materials Based on Content-Based Approach for Nursing Students of STIKES Payung Negeri Pekanbaru", the results of this study say that English language material is needed by students related to hospital, nursing care, medical treatment, diseases, and medicines. The results of his research similar to the research that researcher conducted focusing on materials in nursing.

This research also did interview with the English lecturer of AKPER YPTK Solok, interview had been done to get the information from English lecturer of AKPER YPTK Solok. After interviewed the English lecturer of AKPER YPTK Solok, it can be stated that the students should be prepared to be able to use English in their particular major. The lecturer said that the most important skill that should be mastered by students is speaking skill. Therefore, the students are able to communicate well in work field. Then, the lecturer also said that besides speaking skill the students must be focused on reading skill. It is caused that there are some documents that written by using English. Dealing with grammar and vocabulary, the lecturer also say that both of them are necessary in learning English for nursing students. Dealing with materials, the lecturer used some sources such as from internet eBook, and other sources. Then, the lecturer used to the syllabus that has been prepared by the college. In this case, the lecturer teach English is not totally based on ESP approach. To sum up, it can be concluded that teaching and learning English at AKPER YPTK is not closely based on ESP approach. The lecturer had not conducted the needs analysis before starting learning to find what the students need. The college has been prepared syllabus for English course, so the lecturer teaches English based on that syllabus. 


\section{Conclusion and Suggestion}

Based on the explanation above, it can be concluded that needs analysis is the first step to identify students' need in teaching and learning English process. There are some English skills that the students of AKPER YPTK Solok need in learning English. After analyzed the data it can be shown that; (1) there are some skills and English components that are needed by the nursing students of AKPER YPTK Solok, they are; speaking skill, reading skill, vocabulary mastery, and grammar mastery. (2) This research also found that nursing students of AKPER YPTK Solok want English materials, including grammar and vocabulary related to nursing field to be more focused in teaching and learning process. Thus, in developing English materials for nursing students, the lecturers and decision maker should know what the students and work field need through students; need analysis.

There are some suggestions of this research; first, for the English lecturer who teaches English in specific major is expected to do the need analysis based on the students' need based on their major. Second, for the next researchers are suggested to more focus on the other components of ESP.

\section{References}

Basturkmen, H. (2010). Developing Courses in English for Specific Purposes. London: Palgrave Macmillan

Chegeni, N. (2016). General English Textbook Evaluation: A Closer Look at "Four Corners". Theory and Practice in Language Studies, VI(12), 2325-2330.

Cresswell, John W. (2009). Qualitative Inquiry and Research Design: Choosing among fiveapproaches. United States of America: Sage Publication Inc.

Diana, S., \& Mansur, M. (2018). Need Analysis on English Teaching Materials for Ict Students. ETERNAL (English, Teaching, Learning, and Research Journal) , 4(2), 209. https://doi.org/10.24252/eternal.v42.2018.a6

Dudley, E. and St Johns. (1998). Developments in ESP a Multi-Disciplinary Approach. Cambridge: Cambridge University Press.

ESP in Slovenian Secondary Technical and Vocational Education. English for Specific Purposes World, 1 . online journal available at: http://www.espworld.info/Articles_1/esp.html. (Accessed 23 April 2021)

Gay, et al. (2006). Second Language Writing. Cambridge: Cambridge University Press 
Gulto, Uli Agustina. (2016). Developing English Learning Material for Nursing Students of Borneo University of Tarakan. Journal LingTera Vol. 3 - Number 2, October 2016

Hossain, J. (2013). ESP Needs Analysis for Engineering Students: A Learner Centered Approach. Journal of Presidency University, 2(2)

Kim, Hyun Hyo. (2013). Needs Analysis for English for Specific Purpose course Development for Engineering Students in Korea. International Journal of Multimedia and Ubiquitous Engineering. 8(6): 279-288.

Paltridge, Brian and Sue Starfield. (2013). The Handbook of English for Specific Purpose. Wiley - Blackwell:

Paulina.C. Robinson. (1991). ESP Today: A Practioner's Guide. New York: Prentice Hall.

Strevens, P. (1988). ESP after twenty years: A re-appraisal. In M. Tickoo (Ed.), ESP: State of the art (pp. 1-13). SEAMEO Regional Language Centre. Cambridge University Press

Teaching English for Specific Purposes (ESP). Available at http://www.usingenglish.com/teachers/articles/teaching-english-for specificpurposes-esp.html (Accessed 05 May 2021)

Wahyudi. (2016). Developing English Learning Materials Based on Content-Based Approach for Nursing Students of STIKES Payung Negeri Pekanbaru. Proceeding of the Fourth International Seminar on English Language and Teaching (ISELT-4). 